\title{
Peertechz
}

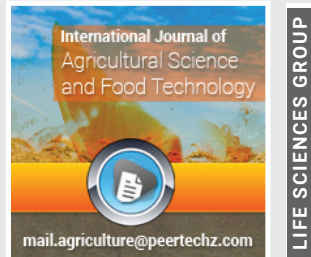

\section{Toxicity of entomopathogenic fungi against Spodoptera frugiperda larvae under laboratory conditions}

\author{
Muhammad Ayaz Shahzad', Muhammad Irfan², Ahmad Abdul Wahab ${ }^{3}$, \\ Farhan Zafar ${ }^{4 *}$, Abdulrehman ${ }^{4}$, Muhammad Shuban $^{4}$ and Muhammad \\ Raheel Saleem ${ }^{4}$ \\ 'Department of Agronomy, Faculty of Agriculture and Environmental Sciences, Islamic \\ University, Bahawalpur, Pakistan \\ ${ }^{2}$ Department of Agronomy, University of Agriculture, Faisalabad, Pakistan \\ ${ }^{3}$ Department of Agronomy, Bahauddin Zikriya University Multan, Pakistan \\ ${ }^{4}$ Department of Entomology, University of Agriculture, Faisalabad, Pakistan
}

Received: 25 October, 2021

Accepted: 16 November, 2021

Published: 17 November, 2021

*Corresponding authors: Farhan Zafar, Department of Entomology, University of Agriculture, Faisalabad, Pakistan, E-mail: farhanzafarkml23@gmail.com

Keywords: Spodoptera frugiperda; Invasive alien species; Maize; Biopesticides; Pakistan

Copyright: @ 2021 Shahzad MA, et al. This is an open-access article distributed under the terms of the Creative Commons Attribution License, which permits unrestricted use, distribution, and reproduction in any medium, provided the original author and source are credited.

https://www.peertechzpublications.com

Check for updates

\section{Abstract}

Maize Fall Armyworm (FAW), Spodoptera frugiperda (Lepidoptera: Noctuidae) is considered an economically important pest and becoming the main threat to food security. This polyphagous pest is widely distributed in various countries of the world especially tropical and subtropical regions. The toxicity of two entomopathogenic fungi such as Metarhizium anisopliae and Beauveria bassiana were evaluated against $2^{\text {nd }}$ instar larvae of FAW under controlled conditions. The results showed that among tested entomopathogenic fungi, B. bassiana was found more toxic than $M$. anisopliae. B. bassiana caused $79 \%$ larval mortality while $M$. anisopliae $59 \%$. M. anisopliae and B. bassiana were showed $\mathrm{LT}_{50}$ of $84.01 \mathrm{~h}$ and $80.99 \mathrm{~h}$, respectively. M. anisopliae and $B$. bassiana were showed $\mathrm{LC}_{50}$ of $1.3 \times 10^{7}$ and $1.8 \times 10^{7}$ spores $\mathrm{ml}^{-1}$, respectively. The current study concluded that Entomopathogenic fungi can give effective control against early instar and further studies are needed to check the efficacy against older instars under field and laboratory conditions.

\section{Introduction}

Fall armyworm, Spodoptera frugiperda belongs to order Lepidoptera and Family Noctuidae has reported from several countries of the globe. It has been reported from Africa in 2016 [1], Pakistan in 2017, India in 2018 (29), China in 2019 [2,3] while native to tropical and subtropical regions of the world [4-6]. Spodoptera frugiperda larvae causes damage to other host plant species belonging to following families; Asteraceae, Fabaceae and Poaceae.

The most important crops that infested with larvae are rice, sorghum, cabbage, cotton, wheat, tomato, millet, beet, groundnut, onion, potato and soyabean [7-10]. Maize, Zea mays commonly known as queen of cereal is an important cereal crop with high reproductivity all over the world [11], source of livestock feed, highly infested with invasive alien insect species, Fall armyworm (FAW) Spodoptera frugiperda [12]. The larvae attack on the tender parts of plants, mostly feed on the young plant parts and even cob [13]. The severe attack of larvae has caused 8-20 million tons per annum maize yield losses in Africa [14]. It is becoming major threat for maize production in Pakistan and as polyphagous in nature, pest is spreading to other host plants.

Therefore, quick actions are needed to control the current pest at early stage to minimize the yield losses. Several management approaches have been adopted to control insect pests such as chemical, biological and botanicals throughout the globe [15]. Chemicals (insecticides) are best methods that give quick and positive response against insect pests but negative impacts on environment, natural enemies and cause resistance to insect pests. 
An ecofriendly and safe management practice should be developed against insect pests to minimize insecticides resistance and environmental pollution in Pakistan [15]. The entomopathogenic microorganisms (fungi, nematodes, bacteria and viruses) are ecofriendly and safe for biological fauna but larvae of Spodoptera frugiperda susceptible to these microbes [16]. However, no entomopathogenic fungi related studies have conducted against this notorious pest of agricultural crops in Pakistan. Therefore, the current study was conducted to check the toxicity of entomopathogenic fungi against larvae under laboratory conditions.

\section{Material and methods}

\section{Insect collection}

Spodoptera frugiperda larvae were collected from different unsprayed fields of maize crops cultivated in district Multan. The collected larvae with maize leaves were shifted into Rearing Laboratory at Institute of Plant Protection.

\section{Maintenance of mass culture}

The culture was maintained in Rearing Laboratory at $26.2^{\circ} \mathrm{C}$, $75 \%$ relative humidity ( $\mathrm{RH})$, and 14:10 h day-light photoperiod.

\section{Toxicity}

Two entomopathogenic fungi, Metarhizium anisopliae and Beauveria bassiana were tested against $2^{\text {nd }}$ instar larvae of $S$. frugiperda. The different spore concentrations $\left(1 \times 10^{4}\right.$, $1 \times 10^{5}, 1 \times 10^{6}, 1 \times 10^{7}$ and $1 \times 10^{8}$ spores/ml) were prepared using Neubauer's improved hemocytometer. The equal age and equal size $2^{\text {nd }}$ instar larvae of second generations were collected from culture and used to perform the current study. There were three replications with 10 larvae per replication which dipped in suspension of $1 \times 10^{8}$ spores $/ \mathrm{ml}$ for $20 \mathrm{~s}$. The treated larvae were shifted into petri dishes containing clean and equal size fresh maize leaves as a food to the larvae. On daily basis, new and fresh maize leaves were provided to larvae for feed. Nothing was used in controls except distilled water. The dose and time mortality responses caused due to fungal infection were observed and recorded or noted.

\section{Statistical analysis}

Percentage mortality of larvae was calculated by using Abbott's formula (Abbott, 1925). Data were statistically analyzed to one-way analysis of variance (ANOVA) using Statistical Package for the Social Sciences (SPSS) software windows version 20.0.

\section{Results and discussion}

Fall armyworm, S. frugiperda is the most destructive pest of many agricultural crops especially maize. It is an invasive species and becoming threat for food security in Pakistan. Chemical control, insecticides is extensively use practice that adopted by majority of farmers against this notorious and emerging pest in the study area that become the cause of environmental pollution and harmful for biological fauna (predators and parasitoids). The negative impacts of insecticides lead to develop an ecofriendly and alternative approach to manage the insect pests especially FAW, S. frugiperda [17]. Microbial control (fungi, bacteria, viruses, protozoa) is an alternative method, larvae of $S$. frugiperda are susceptible to these and consider an important part of integrated pest management $[18,19]$. Isolation of fungi from different stages of $S$. frugiperda (eggs, larvae, pupae, adults) and their infection or toxicity had been reported by many researchers from different countries except Pakistan.

Among tested entomopathogenic fungi, B. bassiana was found more toxic than M. anisopliae. B. bassiana caused $79 \%$ larval mortality while M. anisopliae 59\% (Table 1).

According to [20], M. anisopliae and B. bassiana strains had showed 78.6 and $96.6 \%$ larval mortality at $1 \times 109$ conidia/ $\mathrm{ml}$. Our findings are different to many previous researchers like GARCÍA and BAUTISTA, 2011 [20] who had reported that M. anisopliae isolates cause $97 \%$ mortality while $30 \%$ with $B$. bassiana while $B$. bassiana showed maximum pathogenicity as compared to $M$. anisopliae in the current study. Our current study findings are different from others researchers may be due to variation in larval genetic makeup. The current and previous results variations are due to isolation of fungus strains from different sources. The pathogenicity of microbial agents can vary according to agricultural practices and geographical location. Lezama-Gutierrez R., et al 2001 [21] had reported the similar findings about virulence of fungi. Some researchers had reported $97-100 \%$ larval mortality infected with entomopathogenic fungi [22]. It has already discussed that entomopathogenic fungi show high mortality at early instars and high dose [23]. During the study, only $4 \%$ larval mortality was recorded in control. entomopathogenic fungi

M. anisopliae and B. bassiana were showed $\mathrm{LT}_{50}$ of $84.01 \mathrm{~h}$ and 80.99 h, respectively. M. anisopliae and B. bassiana were showed LC50 of $1.3 \times 10^{7}$ and $1.8 \times 10^{7}$ spores $\mathrm{ml}^{-1}$, respectively as shown (Tables 2,3). [22] had reported that B. bassiana show $19 \%$ mortality and $\mathrm{LC}_{50}$ in the range of $7.4 \times 10^{4}$ conidia $^{-1}$ on new hatch larvae of $S$. frugiperda while $M$. anisopliae isolate $\mathrm{CP}-$ MA1 showed $72.5 \%$ mortality and $\mathrm{LC}_{50}$ at $5.3 \times 10^{5}$ conidia/ml [24-30].

\section{Conclusion}

Toxicity of entomopathogenic fungi against different instar of larvae was conducted in the present study. Each and every concentration of fungus had significant effect against larvae of S. litura. The mortality rate of larvae was increased with

Table 1: Toxicity of Metarhizium anisopliae and Beauveria bassiana against $2^{\text {nd }}$ instar larvae of Spodoptera frugiperda.

\begin{tabular}{|c|c|c|c|}
\hline 1 & Isolates & $\begin{array}{c}\text { Percentage (\%age) mortality } \\
\text { of larvae }\end{array}$ & Source of isolates \\
\hline 2 & B. bassiana & $79.10 \pm 0.11^{\mathrm{a}}$ & Armyworm, Spodoptera exigua \\
\hline 3 & M. anisopliae & $59.20 \pm 0.00^{\mathrm{bc}}$ & Armyworm, Spodoptera litura \\
\hline 4 & Control & $4.99 \pm 0.79^{\mathrm{c}}$ & - \\
\hline 5 & CD@1\% & 0.337 & - \\
\hline
\end{tabular}

Notes: Values with different letters in columns are significantly $(P<0.01)$ different with each other 
Table 2: Dose mortality response of entomopathogenic fungi against Spodoptera frugiperda larvae.

\begin{tabular}{|c|c|c|c|c|c|c|c|}
\hline No. & Isolates & $\begin{array}{c}\mathbf{L C}_{50} \text { spores/ } \\
\mathbf{m l}\end{array}$ & $\begin{array}{c}95 \% \text { fiducial } \\
\text { limit }\end{array}$ & Slope \pm SE & $\chi 2$ & P value & df \\
\hline 1 & $\begin{array}{c}M . \\
\text { anisopliae }\end{array}$ & $1.3 \times 10^{7}$ & $\begin{array}{c}4.0 \times 109- \\
2.9 \times 10^{7}\end{array}$ & $0.599 \pm 0.104$ & 1.124 & 0.669 & 2 \\
\hline 2 & B. bassiana & $1.8 \times 10^{7}$ & $\begin{array}{c}6.1 \times 104- \\
9.3 \times 10^{7}\end{array}$ & $0.454 \pm 0.101$ & 1.981 & 0.589 & 2 \\
\hline
\end{tabular}

LC: Lethal concentration, SE: Standard error, $\chi^{2}$ : Chi square, df: Degree of freedom

Table 3: Time mortality response of entomopathogenic fungi against Spodoptera frugiperda larvae.

\begin{tabular}{|c|c|c|c|c|c|c|c|}
\hline No. & Isolates & $\mathbf{L T}_{\mathbf{5 0}}$ hours & $\begin{array}{c}\text { 95\% fiducial } \\
\text { limit }\end{array}$ & Slope \pm SE & X2 & P value & df \\
\hline 1 & M. anisopliae & $84.01 \mathrm{~h}$ & $70.49-110.10$ & $6.612 \pm 1.299$ & 1.500 & 0.539 & 2 \\
\hline 2 & B. bassiana & $80.99 \mathrm{~h}$ & $75.91-199.12$ & $7.922 \pm 1.143$ & 1.999 & 0.601 & 2 \\
\hline
\end{tabular}

LT: Lethal Time, SE: Standard Error, $\chi^{2}$ : Chi square, df: degree of freedom

increase in concentration of fungus. The current study findings are very important for future studies and helpful in controlling the pest population at laboratory and field conditions.

\section{Acknowledgements}

All authors are highly thankful to concern institutes especially department of Entomology.

\section{References}

1. Goergen G, Kumar PL, Sankung SB, Togola A, Tamò M (2016) First report of outbreaks of the fall armyworm Spodoptera frugiperda (JE Smith)(Lepidoptera, Noctuidae), a new alien invasive pest in West and Central Africa. PloS one 11: e0165632. Link: https://bit.ly/3ovotyx

2. Guo J, Zhao J, He K, Zhang F, Wang Z (2018) Potential invasion of the cropdevastating insect pest fall armyworm Spodoptera frugiperda to China. Plant Protection 44: 1-10. https://bit.ly/3qPtjJw

3. Wu QL, He LM, Shen XJ, Jiang YY, Liu J, et al. (2019) Estimation of the potential infestation area of newly-invaded fall armyworm Spodoptera frugiperda in the Yangtze River Valley of China. Insects 10: 298. Link: https://bit.ly/3ceTTUb

4. Day R, Abrahams P, Bateman M, Beale T, Clottey V, et al. (2017) Fall armyworm: impacts and implications for Africa. Outlooks on Pest Management 28: 196 201. Link: https://bit.ly/3HtPIC8

5. FAO (2018) Integrated management of the Fall Armyworm on maize. A guide for Farmer Field Schools in Africa. Link: https://bit.ly/3HqZXHv

6. Prasanna BM, Huesing JE, Eddy R, Peschke VM (2018) Fall armyworm in Africa: a guide for integrated pest management. Link: https://bit.ly/3oA65Vi

7. Bohnenblust EW, Vaudo AD, Egan JF, Mortensen DA, Tooker JF (2016) Effects of the herbicide dicamba on nontarget plants and pollinator visitation. Environ Toxicol Chem 35: 144-151. Link: https://bit.ly/3nmryBq

8. Cock MJ, Beseh PK, Buddie AG, Cafá G, Crozier J (2017) Molecular methods to detect Spodoptera frugiperda in Ghana, and implications for monitoring the spread of invasive species in developing countries. Scientific reports 7: 1-0. Link: https://go.nature.com/3nhMQjS

9. Hailu G, Niassy S, Khan ZR, Ochatum N, Subramanian S (2018) Maizelegume intercropping and push-pull for management of fall armyworm, stemborers, and striga in Uganda. Agronomy Journal 110: 2513-2522. Link: https://bit.ly/3Ckv8AC

10. Montezano DG, Sosa-Gómez DR, Specht A, Roque-Specht VF, Sousa-Silva JC, et al. (2018) Host plants of Spodoptera frugiperda (Lepidoptera: Noctuidae) in the Americas. African Entomology 26: 286-300. Link: https://bit.ly/31VH4vU
11. Parihar CM, Jat SL, Singh AK, Kumar RS, Hooda KS, et al. (2011) Maize production technologies in India. Link: https://bit.ly/3Cj4kR5

12. Ahmad T, Ali HA, Ghaffar A, Jehan K, Mustafa MU, et al. (2021) Biomorphic Characters of Fall Armyworm, Spodoptera frugiperda (Lepidoptera: Noctuidae) on Maize in Pakistan. Egyptian Academic Journal of Biological Sciences A, Entomology 14: 13-18. Link: https://bit.ly/3niKPDW

13. Bissiwu P, Pérez MJ, Walter NT (2016) Control Efficacy of Spodoptera frugiperda using the Entomopathogens Heterorhabditis bacteriophora and Metarhizium anisopliae with Insecticide Mixtures in Corn. Unpublished master's thesis) University of Earth, Guácimo, Limón, Costa Rica 2016.

14. Rwomushana I, Bateman M, Beale T, Beseh P, Cameron K, et al. (2018) Fall armyworm: impacts and implications for Africa. Invasive Species Compendium 51. Link: https://bit.ly/3CprLlu

15. Ramzan M, Ilahi H, Umar AB, Nasir M, Zahid MK, et al. (2021) Biologica Parameters of Armyworm, Spodoptera litura and Toxicity of Three Insecticides against 3rd Instars Larvae under Laboratory Conditions. Ind J Pure App Biosci 9: 12-17. Link: https://bit.ly/31Uu35N

16. Ramzan M, llahi H, Adnan M, Ullah A, Ullah A (2021) Observation on Fall Armyworm, Spodoptera frugiperda (Lepidoptera: Noctuidae) on Maize Under Laboratory Conditions. Egyptian Academic Journal of Biological Sciences. A, Entomology 14: 99-104. Link: https://bit.ly/3x4cPPb

17. Kumela T, Simiyu J, Sisay B, Likhayo P, Mendesil E, et al. (2019) Farmers' knowledge, perceptions, and management practices of the new invasive pest, fall armyworm (Spodoptera frugiperda) in Ethiopia and Kenya. International Journal of Pest Management 65: 1-9. Link: https://bit.ly/3Fm5g9m

18. Chandler D, Bailey AS, Tatchell GM, Davidson G, Greaves J, et al. (2011) The development, regulation and use of biopesticides for integrated pest management. Philos Trans R Soc Lond B Biol Sci 366: 1987-1998. Link: https://bit.ly/3kGCNmu

19. Opisa S, Du Plessis H, Akutse KS, Fiaboe KK, Ekesi S (2018) Effects of Entomopathogenic fungi and Bacillus thuringiensis-based biopesticides on Spoladea recurvalis (Lepidoptera: Crambidae). Journal of Applied Entomology 142: 617-626. Link: https://bit.ly/3Hoql4J

20. García C, Bautista N (2011) Pathogenicity of isolates of entomopathogenic fungi against Spodoptera frugiperda (Lepidoptera: Noctuidae) and Epilachna varivestis (Coleoptera: Coccinellidae). Revista Colombiana de Entomología 37: 217-222. Link: https://bit.ly/3oA5KC0

21. Lezama-Gutierrez R, Hamm JJ, Molina-Ochoa J, Lopez-Edwards M, PescadorRubio A, et al. (2001) Occurrence of entomopathogens of Spodoptera frugiperda (Lepidoptera: Noctuidae) in the Mexican states of Michoacan, Colima, Jalisco and Tamaulipas. Florida Entomologist 1: 23-30. Link: https://bit.ly/3Ht1g8U

22. Cruz-Avalos AM, Bivián-Hernández MD, Ibarra JE, Del Rincón-Castro MC (2019) High virulence of Mexican entomopathogenic fungi against fall armyworm,(Lepidoptera: Noctuidae). Journal of Economic Entomology 112: 99-107. Link: https://bit.ly/3qFvQWG

23. Ramanujam B, Poornesha B, Shylesha AN (2020) Effect of entomopathogenic fungi against invasive pest Spodoptera frugiperda (JE Smith) (Lepidoptera: Noctuidae) in maize. Egyptian Journal of Biological Pest Control 30: 100. Link: https://bit.ly/3kGALTB

24. Romero-Arenas O, Rivera A, Aragon A, Parraguirre C, Cabrera E, et al. (2014) Mortality evaluation of armyworm (Spodoptera frugiperda JE Smith) by using Metarhizium anisopliae in vitro. Journal of Pure \& Applied Microbiology 8: 5967. Link: https://bit.ly/3wPnPzD

25. Akutse KS, Kimemia JW, Ekesi S, Khamis FM, Ombura OL, et al. (2019) Ovicida effects of entomopathogenic fungal isolates on the invasive fall armyworm Spodoptera frugiperda (Lepidoptera: Noctuidae). Journal of Applied Entomology 143: 626-634. Link: https://bit.ly/3FkfXsP

Citation: Shahzad MA, Irfan M, Wahab AA, Zafar F, Abdulrehman, et al. (2021) Toxicity of entomopathogenic fungi against Spodoptera frugiperda larvae under laboratory conditions. J Agric Sc Food Technol 7(3): 355-358. DOI: https://dx.doi.org/10.17352/2455-815X.000131 
26. Fang W, Leng B, Xiao Y, Jin K, Ma J, et al. (2005) Cloning of Beauveria bassiana chitinase gene Bbchit1 and its application to improve fungal strain virulence. Appl Environ Microbiol 71: 363-370. Link: https://bit.ly/3qH6isv

27. Govind KC, Karki TB, Shrestha J, Achhami BB (2015) Status and prospects of maize research in Nepal. Journal of Maize Research and Development 1: 1-9. Link: https://bit.ly/3wS8cHJ

28. Kalleshwaraswamy CM, Asokan R, Swamy HM, Maruthi MS, Pavithra HB, et al. (2018) First report of the fall armyworm, Spodoptera frugiperda (JE Smith) (Lepidoptera: Noctuidae), an alien invasive pest on maize in India. Link: https://bit.ly/3HurlEk
29. Rwomushana I, Bateman M, Beale T, Beseh P, Cameron K, et al. (2018) Fall armyworm: impacts and implications for Africa. Invasive Species Compendium 51. Link: https://bit.ly/3CxpjQt

30. Shylesha AN, Jalali SK, Gupta A, Varshney R, Venkatesan T, et al. (2018) Studies on new invasive pest Spodoptera frugiperda (JE Smith)(Lepidoptera: Noctuidae) and its natural enemies. Journal of Biological Control 32: 145-151. Link: https://bit.ly/3nhNeik
Discover a bigger Impact and Visibility of your article publication with Peertechz Publications

\section{Highlights}

* Signatory publisher of ORCID

* Signatory Publisher of DORA (San Francisco Declaration on Research Assessment)

* Articles archived in worlds' renowned service providers such as Portico, CNKI, AGRIS, TDNet, Base (Bielefeld University Library), CrossRef, Scilit, J-Gate etc.

* Journals indexed in ICMJE, SHERPA/ROMEO, Google Scholar etc.

* OAI-PMH (Open Archives Initiative Protocol for Metadata Harvesting)

* Dedicated Editorial Board for every journa

* Accurate and rapid peer-review process

* Increased citations of published articles through promotions

* Reduced timeline for article publication

Submit your articles and experience a new surge in publication services (https://www.peertechz.com/submission).

Peertechz journals wishes everlasting success in your every endeavours.

Citation: Shahzad MA, Irfan M, Wahab AA, Zafar F, Abdulrehman, et al. (2021) Toxicity of entomopathogenic fungi against Spodoptera frugiperda larvae under laboratory conditions. J Agric Sc Food Technol 7(3): 355-358. DOI: https://dx.doi.org/10.17352/2455-815X.000131 